\title{
Transnational Corporations and Network Effects of a Local Manufacturing Cluster in Mobile Telecommunications Equipment in China
}

\author{
Henry Wai-chung Yeung, Weidong Liu and Peter Dicken
}

Forthcoming in World Development, Vol.34, 2006.

\section{Henry Wai-chung Yeung,}

Associate Professor, Department of Geography, National University of Singapore, 1 Arts Link, Singapore 117570. Email: geoywc@nus.edu.sg

\section{Weidong Liu,}

Professor, Institute of Geographical Sciences and Natural Resources Research, Chinese

Academy of Sciences, Beijing. Email: liuwd@igsnrr.ac.cn

\section{Peter Dicken,}

Emeritus Professor, School of Geography, University of Manchester, Manchester, M13 9PL,

UK. Email: P.Dicken@Manchester.ac.uk

\section{Acknowledgement}

An earlier version of this paper was presented at the Annual Meeting of the Geographical Society of China, Sun Yat-sen University, Guangzhou, China, 3-5 December 2004, and the Annual Meeting of the Association of American Geographers, Denver, USA, 5-9 April 2005. We thank the conference participants for their comments. We would like to acknowledge the following institutions for funding the fieldwork of this project: the Economic and Social Research Council, UK (Grant No: R000238535), the Institute of Geographical Sciences and Natural Resources Research, Chinese Academy of Sciences, China (IGSNRR Director Grant W202), and the National University of Singapore (R-109-000-050-112). We are also grateful to the interviewees participating in this project. Three referees of World Development have offered helpful comments for our revisions. All errors and mistakes are, however, our own responsibility. 


\section{Transnational Corporations and Network Effects of a Local Manufacturing Cluster in Mobile Telecommunications Equipment in China}

\section{Summary}

The local formation, and benefits, of industrial clusters have received considerable research attention during the past decade. We argue that the existing literature has underestimated the role of external economies of collective bargaining and production capacity accruing to firms in clusters that are derived from traded relationships with institutions, firms and customers outside local clusters. We define these benefits as non-cluster economies of traded interdependencies among firms in clusters. To illustrate our arguments, we examine the formation in Beijing, China, of one of the world's few mobile telecommunications manufacturing clusters. We show how Nokia, the lead firm in the local industrial cluster, is able to create non-cluster external economies for its key suppliers co-locating in this purposespecific industrial cluster.

Keywords: Asia - Beijing, networks, clusters, transnational corporations, suppliers, Nokia 


\section{INTRODUCTION}

The localized formation, and benefits, of industrial clusters have received considerable research attention during the past decade. In some extreme versions of this huge literature, clusters are hailed as a universal panacea for local and regional development (e.g. Porter, 1998; 2000; cf. Malmberg and Maskell, 2002; Malmberg, 2003; Martin and Sunley, 2003; Benneworth and Henry, 2004; Perry, 2005). Porter (1998), for example, has developed a strategy-based concept of cluster development in different urban and regional contexts. He defines clusters as "geographic concentrations of interconnected firms, specialized suppliers, service providers, firms in related industries, and associated institutions in particular fields that compete but also cooperate" (Porter, 1998: 197). Despite its wide adoption in the policy circle, this definition of clusters has been strongly criticized by Martin and Sunley (2003: 10) as a chaotic concept that lacks "clear boundaries, both industrial and geographical" (see also Markusen, 1999). In this paper, we take a stricter definition of clusters as localized territorial ensembles in which firms within particular industries and sectors engage in interdependent economic transactions along specific production chains that are facilitated, but not necessarily determined, by spatial proximity. In particular, we are interested in local clusters that are fairly delimited in their industrial and geographical boundaries. The precise spatial definition of a "local" cluster is somewhat contingent, although we certainly eschew the extraordinarily vague and elastic definitions used by Porter and others to describe interlinked economic activities at the regional and sometimes international scales. In general, we may define a "local" cluster at such a spatial scale that allows sufficient day-to-day and face-to-face communications: either at the metropolitan level if the city is relatively small and its traffic is low, or at the district level if the city is large and its traffic is heavy.

The emergence of clusters, however, is not a recent phenomenon. Indeed, the spatial agglomeration of economic activities has long been recognized and explored in a wide range 
of literature (Hirschman, 1958; Lloyd and Dicken, 1972; Phelps, 1992; Amin and Thrift, 1994; Markusen, 1996; Storper, 1997; Ellison and Glaeser, 1999; Maskell and Malmberg, 1999; Schmitz and Nadvi, 1999; Cooke, 2001; Cumbers and Mackinnon, 2004; Perry, 2005). This literature argues that cluster development is significantly embedded in networks of relational assets and geographical proximity particularly at the local and regional scales such that "territorialization is often tied to specific interdependencies in economic life" (Storper, 1997: 20). Such social processes as norms and conventions, collective learning, and localized capabilities help to define these specific interdependencies and subsequent territorial tendencies. When tapped by firms in specific localities, these interdependencies provide a significant source of location-based advantages through both competition and cooperation. In these studies, the positive aspect of clusters is arguably demonstrated through their greater likelihood of reducing transaction costs and promoting inter-firm learning, innovation, and knowledge transfer/spillover and, as a result, enhancing local competitiveness.

In this paper, we consider these possible economies of traded and untraded interdependencies as internal to peculiar clusters. They are developed organically within clusters and are, therefore, less likely to be shared and available to non-cluster firms. We argue, however, that there is another important - and yet critical - aspect of cluster economies that is often underestimated in the existing literature. These are external economies of collective bargaining and production capacity accruing to firms in clusters, but deriving from traded relationships with institutions, firms and customers outside local clusters. We define these benefits as non-cluster economies of traded interdependencies among firms, particularly suppliers, in local clusters. These economies are external to those derived from within clusters through interaction between lead firms and their local and international suppliers. The realization of these economies is not necessarily an outcome of spatial proximity per se, but rather a product of relational networks that bind these cluster firms in trust relationships and, 
thereby, allow them to tap into external economies outside these clusters. In this paper, we call these "network effects" in order to demonstrate that mere co-location does not necessarily guarantee the attainment of external economies in localized industrial clusters.

To illustrate our arguments, we examine the formation, in Beijing, China, of one of the world's few mobile telecommunications manufacturing clusters, known as the Xingwang Industrial Park. We believe such a detailed case study is important precisely because, as Martin and Sunley (2003: 29) note, "[t]he empirical case for clustering remains in its infancy and repeatedly makes the mistake of jumping from particular associations to general causality and applicability". Our choice of the case study approach is premised on the fact that quantitative data on this newly emerged manufacturing cluster remain unavailable and our primary objective is to identify non-cluster based economies through relational networks - an approach that requires intensive investigation into and highly contextualized appreciation of inter-firm and extra-firm relationships. Drawing upon personal interviews and secondary materials in China, we show how Nokia, the lead firm in a local industrial cluster, is able to create non-cluster external economies for its key suppliers co-locating in this purpose-specific industrial cluster. We aim, therefore, not only to add additional empirical evidence to existing studies of local clusters in developing countries (see Christerson and Lever-Tracy, 1997; Wang and Wang, 1998; Eng, 1999; Schmitz and Nadvi, 1999; Wang and Yeung, 2000; Zhou and Tong, 2003; Liu et al., 2004; Schmitz, 2004; Depner and Bathelt, 2005), but also to contribute to further theory development.

In particular, the literature on industrial clusters in developing countries, through its interaction with the global value chain perspective (see Bair and Gereffi, 2001; Humphrey and Schmitz, 2002; Gereffi et al., 2005), has brought our analytical attention to the critical importance of external linkages and joint action in understanding the formation and development outcomes of industrial clusters. Two leading proponents in this field, for 
example, have argued that "Both relationships amongst firms and between firms and support organizations [in clusters] have been a focus of attention. Relationships with agents outside the cluster are given much less attention, or described as predominantly arm's-length and market-based" (Humphrey and Schmitz, 2004a: 95). This critique of the cluster literature is very relevant to this study as the Nokia cluster originates from the strategic agglomeration of a lead firm and its global suppliers. It is not an endogenous and self-organized form of cluster development that characterizes many of the world leading clusters (e.g. Silicon Valley and Third Italy). To understand the formation and rationality behind this "intentional cluster", we need to incorporate a broader perspective that takes into account of both economies internal to the cluster and the external linkages and joint action of key actors co-locating in the cluster. Our analytical approach thus supports Humphrey and Schmitz's (2004b: 371) conviction that "the analysis of local agglomeration and cooperation effects has to be complemented by the study of relationships with actors outside the cluster, especially in export-oriented clusters".

More specifically, the Nokia cluster of mobile telecommunications manufacturing in Beijing, China, is an important case study for two reasons. First, it is relatively unusual as a brand new, purpose-specific cluster, comprising one lead firm, Nokia-Capitel (a joint venture), and 17 major suppliers within an area of 50 hectares in 2005. After the second phase of the industrial park is completed, there will be over 30 major suppliers within an area of 100 hectares. Unlike many of the clusters identified in Porter's (1998) study, the relatively homogeneous nature of the Xingwang cluster makes it easier for us to delineate its industrial and geographical boundaries (cf. Martin and Sunley, 2003). It serves as an ideal-typical form of a highly localized cluster. Second, its location within the Beijing Economic and Technological Development Area (BDA, hereafter), a state-designated growth zone of 39.8 square kilometers at the southeast fringe of China's capital city, essentially means that the cluster is embedded in a wide range of local/non-local and economic/non-economic 
relationships that significantly challenge Porter's vague and narrow notion of clusters. The dynamic evolution of the Nokia cluster also allows us to identify the key internal and external forces behind its formation and growth.

The paper is organized into three major sections. The next section sets up our conceptual arguments that focus on the role of non-cluster external economies as one of the causal mechanisms through which clusters are developed. Here, we develop the notions that economies of clusters can be further decomposed into two types: those within and those outside clusters. In the second section, we provide a general overview of the development of a manufacturing cluster in Beijing, China. The third section focuses on how Nokia and its key suppliers in the local cluster are able to capitalize on external economies of traded interdependencies to benefit from the synergistic effects of their network strength and the production economies enhanced by external customers. The concluding section re-examines clusters as a chaotic concept and suggests some implications for economic development.

\section{FROM CLUSTER ECONOMIES TO ECONOMIES OF CLUSTERS: EFFECTS OF \\ RELATIONAL NETWORKS}

Academic and policy studies of clusters since the 1990s have become a kind of cottage industry in itself. There is no shortage of conceptual models of cluster development. Neither is there a lack of comprehensive and yet critical reviews of cluster studies (e.g. Malmberg and Maskell, 2002; Martin and Sunley, 2003; Benneworth and Henry, 2004). Perry (2005: 10), for example, summarizes this critical view on cluster studies very well: "The growing identification of clusters does not of itself indicate universal trends are affecting the organization and location of business activity. Neither does the existence of a cluster indicate that a particular set of advantages are being gained by its participants". In this section, we briefly outline several influential models of cluster development before we delineate different types of cluster economies in these models. While Michael Porter's (1998) model of cluster 
development is certainly the most influential one in the policy circle, we have chosen not to rehash it here for the same reasons that Martin and Sunley (2003) have proposed - its vagueness, ambiguity and one-size-fits-all approach to understanding clusters and their territorial development. Equally, we will not delve into the original formulation of the underlying idea of clusters in the writings of Alfred Marshall and others on the spatial concentration of specialized industries and the role of such external economies as the availability of skilled labor, the development of supporting trade, and the industrial and production specialization of firms. While these Marshallian ideas remain relevant to today's cluster development, we argue that there are new dimensions of cluster development that remain underestimated in the existing literature, particularly external linkages and joint action (see Schmitz, 1999; 2004; Schmitz and Nadvi, 1999; Perry, 2005).

Moreover, the spatial, institutional, and discursive contexts of cluster development are profoundly different in today's global economy compared with those prevailing in Marshall's day. The spatial scales and forms of clusters are increasingly differentiated and enlarged in contemporary contexts (see Phelps, 2004; Perry, 2005). Local and regional institutional capacity in many places has been increasingly strengthened in recent years, partly due to a widespread process of rescaling and devolution of governance, particularly at the economic level (Goodwin and Painter, 1996; MacLeod and Goodwin, 1999; MacLeod, 2001a). Concomitantly, the discursive context in this quest for local and regional development in association with growing and developing "institutional thickness" (Amin and Thrift, 1994) at the local scale has been overwhelmingly pro-growth and pro-business. In other words, the development of a cluster in a local setting, whether imaginary or real, is inevitably going to attract a great deal of policy and public interests. Clusters are virtually seen as an unquestionable solution to local and regional development problems. 


\section{(a) Three ideal-typical models of industrial clusters}

How then do we know whether clusters are indeed good or bad? In this respect, we do need conceptual models to guide our understanding of the nature and dynamics of cluster development. Here, we look to Gordon and McCann (2000) for their relatively clear and precise review of three major ideal-typical models of industrial clusters:

(1) the classic model of pure agglomeration;

(2) the industrial complex model and

(3) the social network model.

These three ideal-type cluster models are summarized in Table 1. In the first model, industrial clusters are developed through the natural agglomeration of economic activities, so that firms in similar and different industries can enjoy external economies from their embeddedness in these clusters. However, such firms may not have traded interdependencies with other firms in the cluster. The agglomeration economies in these industrial clusters originate from the development of a local pool of specialized labor (reduction in search costs), the increased local provision of non-traded inputs specific to an industry (realization of economies of scale), and the maximum flow of information and ideas (spillover of product and market knowledge). The basic assumption of this model of agglomeration economies is that the local cluster is essentially an "open system". Any firm may enter and exit the cluster, provided that it is "willing to pay a market rent level which reflects the net value of spatial externalities (as well as other inherent locational advantages)" (Gordon and McCann, 2000: 518). This approach to cluster development is most commonly found in neoclassical industrial and urban economics (e.g. Fujita and Thisse, 1996; Ellison and Glaeser, 1999; Fujita et al., 1999).

Table 1 here

$* * * * * * * * * * * * * *$ 
Industrial clusters can also develop through deliberate construction of industrial complexes that minimize transaction costs in inter-firm trade through spatial concentration and proximity. In this model, cluster-based firms are able to enjoy lower transport and logistics costs and lower uncertainties in transactions through mutual interactions facilitated by physical proximity (see Table 1). The raison d'être of this type of industrial cluster is that firms must engage with each other through traded interdependencies. Gordon and McCann (2000: 519) note that "where there are strategic interactions among the locational decisions of a few firms, and/or where viability depends on co-location, concerted planning of these decisions by the firms concerned (and long-term production/contracting arrangements) is necessary, with or without state encouragement". These clusters are particularly common in the oil refining, chemicals, pharmaceuticals and automobile industries throughout the world (see Dicken, 2003; Cumbers, 2000). They are effective only if spatial proximity enhances inter-firm transactions along particular production chains via the formalization of just-in-time production and supply chain management practices (e.g. the Toyota City; see Sayer, 1986; Womack et al., 1990; Sadler, 1994; Fujita and Hill, 1995; Reid, 1995).

There is thus a great deal of industrial concentration and specialization of firm activities in this type of cluster than is found in the model of pure agglomeration economies. There is also much less scope for untraded interdependencies than in the first model. Nevertheless, most empirical studies of this model of industrial complexes tend to focus excessively on inter-firm transactional dynamics within clusters and overlook the possible connections and linkages that these cluster firms might have with other firms outside these industrial complexes - a significant shortcoming partially addressed by the third model on social networks. This omission is not surprising given that most studies of industrial complexes take inter-firm transactions, measured quantitatively in input-output models, as their main unit of empirical analysis. 
The third model of cluster formation identified by Gordon and McCann (2000) refers to the important role of local networks of inter-personal relationships, trust and institutionalized practices in facilitating the coming together of firms in particular localities. Much of the recent revival of the so-called "new regionalism" literature has been devoted to explicating how "institutional thickness" contributes to local and regional clustering of economic activities (see Amin and Thrift, 1994; Lovering, 1999; MacLeod, 2001b; Coe et al., 2004). In this genre of the literature, strong social networks, institutionalized through cooperative practices, can enable tacit knowledge to develop and be transferred among firms in clusters that, in turn, further contributes to technological innovations and knowledge development (see Table 1). Firms embedded in such social networks are conceived as being highly localized in their innovative and production activities. As such, the role of external economies in these untraded interdependencies is akin to the Marshallian notion of "atmosphere". These agglomeration economies emanate from such tangible assets as common services and ancillary facilities to such relational assets as cooperative spirit, local "buzz", social codebooks and conventions (see also Storper, 1995; 1997; Henry et al., 1996; Bathelt et al., 2004; Maskell and Lorenzen, 2004; Morosini, 2004; Tallman et al., 2004).

Most empirical studies of cluster formation in this genre tend to focus on clusterspecific external economies of spatial proximity in relation to promoting learning, innovation, and knowledge transfer among different, and often unrelated, firms. Two problems emerge from this model of cluster development. First, positive benefits derived from firms' embeddedness in localized social networks are a form of external economies not too different from those identified in the first model of industrial agglomeration. Second, the excessive focus on localized social networks tends to ignore the articulation of these firms in regional and global networks that operate well beyond the local scale. In fact, many innovative firms in local clusters are as strongly embedded in non-local networks of knowledge communities and 
corporate organizations as they are locally embedded (see Bunnell and Coe, 2001;

MacKinnon et al., 2002; Amin, 2003; Amin and Cohendet, 2004; Morosini, 2004; Wolfe and Gertler, 2004). Malmberg (2003: 155) perceptively reflects on this "local" departure in most writings on clusters:

Here, the role of large global firms tends to cause unease. The 'true' actors of such milieus are locally owned small and medium-sized firms, while globally oriented transnational corporations (TNCs) one way or another are seen as alien to the idea of a dynamic local milieu. This is most explicitly expressed in some of the work on industrial districts, but the same model of thought is implicitly expressed in much work on regional clusters.

Recent work on industrial clusters in developing countries has incorporated the global value chain approach to explain cluster development and governance issues (see Bair and Gereffi, 2001; Gibbon, 2001; Humphrey and Schmitz, 2002; Schmitz, 2004; Gereffi et al., 2005). Through comparative and detailed case studies, this emerging literature has convincingly shown the critical role of external linkages and joint action in determining the upgrading possibilities of different industrial clusters in developing countries.

\section{(b) Conceptualizing territorial sources of cluster economies}

While Gordon and McCann (2000) provide a helpful typology of different models of cluster development, however, they do not go far enough in specifying the relevance of each model for different spatial and development contexts (apart from their brief example of the Greater London region). Martin and Sunley (2003: 16), for example, argue that their tripartite theoretical schema "fails to specify the particular circumstances, economic and spatial, under which one theoretical model should be more applicable than another... By their very nature, ideal typical models never fit reality exactly, and in this case it is difficult to think of a pure agglomeration economies cluster, a pure industrial complex cluster, or a pure network cluster". In reality, we are likely to find elements of these different models in a single industrial cluster. As our case study in the next two sections will reveal, Nokia's Xingwang Industrial Park is a local cluster modeled after an industrial complex concept in the automobile industry. But 
there are significant external economies - derived from cluster and non-cluster sources emanating from strong social networks and trust relationships between Nokia and its major suppliers. The crucial precondition to this cluster formation therefore hinges on the role and presence of positive externalities facilitated, but not determined, by spatial proximity and inter-firm relationships.

The main conceptual issue here then rests with our understanding of these "positive externalities". Are they merely cluster economies to be tapped into through spatial agglomeration of economic activities? Or are we able to conceptualize different territorial sources of economies of clusters? As noted by Phelps (2004: 984), “[t]he concept of external economies itself tends to be locked into an idiographic realm of self-contained places defined at whatever scale". All three models above seem to point to cluster economies that emanate from within these industrial clusters as if they are bounded spaces (see Table 1). These external economies are often used to explain the formation of industrial clusters, when in reality they might indeed be as much the cause (ex ante) as the outcome (ex post) of these clusters. Questioning Porter's (1998) model of cluster formation, Perry (2005: 7) perceptively offers us "a reminder not to assume that contemporary business structures explain why the cluster came about". We really need to explain not ex ante the composition of a cluster but to isolate the characteristics that predict the creative forces behind the formation of successful and integrated regional economies. Take, for example, the role of maximum flow of information and ideas in the pure agglomeration model. It is questionable that this maximum flow can be attained without firms choosing to cluster together. The presence of this external economy in an industrial cluster is therefore contingent upon the agglomeration of firms in the first place, an observation, incidentally, made by Alfred Weber (1909) almost a hundred years ago. The same confusion over causality also occurs in the industrial complex model and the social networks model (see Table 1). In both models, reduction in transaction costs and 
enjoyment of relational assets are a consequence of the presence of clusters, not the explanations of their formation, whether industrially or territorially.

From this perspective, then, we need to distinguish the causal explanations of cluster formation in two phases: (1) before the existence of any cluster in a particular location and (2) after the initial clustering of economic activities in this particular location. Most external economies identified in the three models above tend to refer to the second phase, i.e. when specific industrial clusters are already in existence. But what about the initial preconditions through which clustering might be made possible? Maskell and Lorenzen (2004: 991-992) have recently pointed out this problem: "no general understanding has yet emerged regarding the paramount reason why the separate entities [firms] became co-localised in the first place, what has made them stick together, what the effects may be and - at an even more basic level - why this matters at all”. This lacuna in explaining cluster formation is particularly problematical in the case of developing countries as some of the dynamic and export-oriented clusters are newly developed through the external linkages between actors in specific locality and global production networks. They are not necessarily driven by localized knowledge spillovers or a cooperative milieu. Rather, these clusters grow out of intentional strategies that connect locally based actors and lead firms in global production networks (Henderson et al., 2002; Coe et al., 2004). In tapping into these global production networks, actors in these localities in developing countries pull together their resources and strategic efforts to attain what Schmitz (1999) calls "collective efficiency".

To theorize this initial clustering of economic activities among firms, we need to broaden our conception of external economies to include non-cluster sources of economies that may provide incentives for firms to cluster. Drawing upon, but unlike, the earlier three models, this approach to cluster formation does not assume the presence of clusters, but rather seeks to explain them. In this broadened conception of external economies, we think of 
benefits accruing to firms in clusters that are not necessarily an outcome of spatial proximity, but rather a product of relational networks - the so-called "network effects" or, in the words of Phelps (2004: 985), "network externalities". These external economies are available to firms embedded in relational networks that need not be territorially organized in the form of clusters. More specifically, lead firms and their key suppliers in global production networks tend to engage in long-term collaborative relationships. The strength of ties in these relational networks often determines whether suppliers will follow a lead firm to establish supply chain operations within the vicinity of the lead firm's new production facility. Co-location of a lead firm and its key supplier tends to strengthen their existing relational ties. This aspect of externalities should be considered as network-based rather than cluster-based. However, spatial proximity can enhance the creation and capture of these external economies, thereby providing these firms with economic incentives to cluster together. Our conception of the complex, and yet mutually constitutive, relationships between clusters and networks thus differs markedly from Maskell and Lorenzen (2004) who see networks and clusters as two distinct forms of market organization. They argue that networks are preferred in industries when uncertainty is low or modest, whereas clusters tend to be more common in industries characterized by high uncertainty or ambiguity. We believe, however, that it is external economies, not industry uncertainty, that primarily drive firms to co-locate in specific clusters. Once formed, such industrial clusters embedded in strong relational networks can be interpreted as social communities that are well described by Morosini (2004). The remaining issue is what constitutes external economies - cluster-sourced as well as non-cluster-sourced?

In particular, we conceive two forms of non-cluster economies of traded interdependencies between lead firms and their key suppliers: collective bargaining through relational networks and enhanced production capabilities through external customers. First, a closely-knit group of firms in relational networks can command considerable collective 
bargaining power, by virtue of their synergistic network effect, in relation to other firms and institutions in particular local and/or regional economies. This collective bargaining power, while predicated on the relational proximity of network firms, can be substantially enhanced through physical proximity. For example, supplier firms in particular global production networks driven by lead firms can share the external economies of their collective strength when they bargain with other firms and institutions for material inputs, transport and logistical requirements, physical infrastructure, and so on. They are thus more likely to achieve considerable external economies of scale prior to cluster formation. Through their collective bargaining strength, lead firms in major global production networks are more likely to be able to secure the initial precondition for cluster formation - choosing a strategic location that eventually grows into a sizeable industrial cluster and incorporates most network member firms. Once this clustering process is set in motion, these firms are able to enjoy many of the cluster-specific external economies identified in Table 1. Our conception of collective action is slightly different from the views of Schmitz $(1999 ; 2004)$ and Humphrey and Schmitz (2002) who emphasize the role of local actors in achieving collective efficiency through joint action. Our explicit focus on the interaction between lead firms, their global network partners, and local actors bridges the analytical gap in connecting external linkages to localized collective action in this genre of work on industrial clusters.

Second, firms in global production networks can enhance their production capacity and capabilities through non-network customers. These increasing external economies of scale are again not necessarily limited to firms in clusters as conceived in the literature reviewed above. Instead, cluster firms can achieve external economies of scale through production for lead firms in different global production networks, thereby reducing dependence on major customers within or outside specific clusters and avoiding lock-in effects. Firms in industrial clusters are thus participating in multiple and sometimes 
competing global production networks. These network effects of increasing economies of scale, however, do not imply that supplier firms are not keen to cluster around their lead customers. There is still a whole range of cluster-based external economies that can be tapped into through geographical agglomeration. What is important here is that non-cluster sources of scale economies can sometime be critical in enhancing the production capacity and capabilities of these supplier firms, enabling them to be better endowed with resources to split their production into different locations. This tendency for supplier firms to co-locate with their lead customers in different clusters is stimulated by the global trend of outsourcing and subcontracting of production by lead firms to contract manufacturers that provide original equipment manufacturing (OEM) and electronic manufacturing services (EMS) (see Dicken, 2003; Sturgeon, 2003; Gereffi et al., 2005).

To sum up tentatively, we have provided in this section an overview of different models of industrial clusters and their associated external economies. We have also identified the territorial sources of these external economies within and outside industrial clusters. We have argued that non-cluster sources of external economies are not only underestimated in the literature, but also that they can be potentially critical in firms' decisions to cluster together in specific territorial ensembles. Our approach seeks to broaden current conceptions of external economies beyond those available and identified in pre-existing clusters. Instead, we believe that these non-cluster external economies of collective action and relational networks might offer some insights into the initial formation of industrial clusters precisely because these economies are not contingent on the existence of clusters in the first place. In other words, non-cluster external economies exist independently of clusters. They contribute to the initial advantages enjoyed by lead firms and their suppliers in global production networks. These "network effects" of collective bargaining power and enhanced production capacity can provide the necessary initial precondition of cluster formation, namely external economies of 
scale. And yet, unlike those described in Table 1, these external economies of scale can be created and captured irrespective of cluster formation (see conclusion for general implications for economic development). While complementing the three models of industrial clusters, our approach allows for an analysis that links firms in clusters to other firms and institutions outside these clusters (see also Bunnell and Coe, 2001; Schmitz, 2004; Wolfe and Gertler, 2004; Gereffi et al., 2005).

In the next two sections, we examine a particular mobile telecommunications manufacturing cluster in Beijing, China, and trace the non-cluster economies of traded interdependencies among firms in this cluster. Our empirical data are based on personal interviews conducted in November and December 2002 by the authors with officials from the Beijing Economic and Technological Development Area and the China Customs in BDA, top executives in the Xingwang Industrial Park, Beijing Capitel Nokia Mobile Telecommunications Ltd. (Nokia-Capitel), Nokia's suppliers in the Park, and Nokia's logistics handling agent. These interviewees were chosen on the basis of their role in developing the Nokia industrial cluster. Some follow-up interviews were also conducted by one of the authors in 2003, 2004 and 2005. We also use official data and published reports to supplement our primary data.

\section{THE EMERGENCE OF A MANUFACTURING CLUSTER IN A SOCIALIST}

\section{MARKET ECONOMY}

Since the promulgation of its open-door policy in late 1978, China has experienced an interesting spatial phenomenon known as the "zone fever". Today, there are literally thousands of various development zones modeled after export-processing zones and free trade zones that were popular during the 1950s and the 1960s in developing countries. These development zones - also known as "enterprise zones" in the UK and the US (Potter and Moore, 2000; Yeung, 2004), and officially known in China as economic and technological 
development zones - gained a new lease of life in China from 1984 onwards, largely due to the prudent "gradually opening door" strategy implemented by the late patriarch Deng Xiaoping. Initially, they were designated by the central government as an "enclave" (or a pilot area) to attract foreign direct investment, to test the applicability of market economy, and to develop relatively advanced and export-oriented manufacturing activities at a time when the country was still a socialist central-planning economy. Between 1984 and 1992, numerous development zones were established in the coastal cities to attract foreign manufacturing investments seeking low cost production locations (see Lin, 1997; Duckett, 1998; Marton, 2000; Cartier, 2001). The spatial direction of the development of this kind of zones was significantly geared towards other areas than those coastal cities after 1992, when the Chinese top leaders were pushed by Deng Xiaoping's talk during his trip to southern China, to undertake further reforms. Thus the post-1992 period witnessed a rapid proliferation of the development zones, approved by the Chinese governments at various levels. Those approved by the State Council, the highest governing body in the Chinese central government, are known as state-level development zones that belong to a more limited group of development areas enjoying special state privileges. By 2003, 54 such state-level development zones had been officially approved by the State Council.

The Beijing Economic and Technological Development Area (BDA) was officially approved in August 1994 by the State Council as a state-level development zone, with an initial area of 15.8 square kilometers (see Figure 1). ${ }^{1}$ Its infrastructural construction, however, had already started in October 1992. Despite its official status as one of the latest development zones approved by the central government in the coastal region, the BDA had experienced very rapid growth between 1995 and 2004 - with an annual GDP growth rate of over $60 \%$, faster than most other special economic zones in China. By May 2005, the BDA had hosted 1691 enterprises with a combined investment of US\$9.6 billion. Foreign wholly- 
owned or joint ventures constituted 425 enterprises (including 64 of the Fortune 500 TNCs) and their combined investment had reached US\$7.3 billion. The average investment per foreign enterprise was US\$17.2 million -about 5 times more than the national figure (Interview with the BDA officials, June 2005). At the end of 2004, the BDA's GDP amounted to RMB $\$ 12.7$ billion (US\$1.5 billion), its gross industrial output was RMB $\$ 68$ billion (US\$8.2 billion), and export value US\$2.2 billion. Foreign enterprises in high tech sectors accounted for some $86 \%$ of this massive industrial output and export. The BDA now ranks 5th among 54 state-level special economic zones in terms of its comprehensive economic strength.

Figure 1 here

$* * * * * * * * * * * * * *$

Telecommunications and IT constitute the most important of its five pillar industries while the Nokia cluster is clearly the BDA's primary anchor. In 2004, the sales of NokiaCapitel and its suppliers (to other assemblers) was RMB \$26 billion (US\$3.15 billion), around $38 \%$ of BDA's total sales. In this context, the establishment of the Nokia-centered Xingwang (International) Industrial Park provides an extremely interesting case study of the formation of one of the world's few mobile telecommunications manufacturing clusters. As Perry (2005: 15) argues in his critical review of cluster studies, we need "an explanation of clusters that recognizes an individual context to their formation and significance". The Xingwang (International) Industrial Park is a mobile-phone manufacturing cluster specifically developed by Nokia (China) Investment Co. Ltd. (NCIC) and the BDA to bring together Beijing Capitel Nokia Mobile Telecommunications Ltd. (Nokia-Capitel) and its major suppliers in a purposespecific industrial cluster. The original idea of establishing a telecom cluster in China came from Nokia itself. In 1998 when China's mobile phone market started to boom, NCIC decided to look for a new production site to expand its production capacity. The expansion of its 
existing joint venture plant with the Capitel Group in Beijing's urban area was spatially constrained by the unavailability of land. The new site in the BDA (today's Xingwang Industrial Park) is 100 hectares in size (50 in the first phase and 50 in the second), much larger than the urban Beijing site. Although Nokia was interested in adopting a new business model in the planned new plant, it had no concrete idea how to create a telecom cluster until its managers visited the automobile assembly plant of Volkswagen in Barcelona, Spain, in late 2000. Indeed, the business model of assembler and suppliers cluster is nothing new in the automobile sector, where JIT or lean production is widely adopted to cut down production costs and to respond quickly to market change in the sector (Womack et al., 1990). JIT clusters have been demonstrated by many studies on the automobile sector to be efficient in reducing inventory, which is critical to cutting down production costs and increasing flexibility of production (i.e. customized production). Apparently, Nokia wished to learn from the mature automobile sector how to manage and control its supply chain efficiently without engaging in too much in-house production (Interview with Nokia-Capitel, December 2002). Arguably, increasing time efficiency and adopting production customization were the two major reasons behind the introduction of the new business model by Nokia in the Xingwang Industrial Park.

When NCIC decided in 1999 to relocate its manufacturing operations to a new location within the BDA, it stimulated the establishment of the Xingwang (International) Industrial Park (see Figure 1). The Park is a cooperative joint venture between the BDA and NCIC - the BDA provides land and NCIC contributes to physical buildings. The main tenant, Beijing Capitel Nokia Mobile Telecommunications Ltd. (Nokia-Capitel), is a 50-50 joint venture company established in 1995 between NCIC and the China Putian Beijing Capitel Co. Ltd. Nokia-Capitel is a very significant investment for both Nokia and China. It became: 
1. Nokia's largest joint venture in China and one of China's largest foreign joint ventures in the IT sector. Between 2000 and 2005, Xingwang has attracted US\$1.2 billion investment and created 18760 jobs;

2. the leading producer of mobile telecommunications equipment in China and Nokia's largest mobile phone production base in the world; and

3. Beijing's leading exporter (one fifth of the total export by foreign firms in Beijing in 2003, including foreign wholly-owned and joint ventures) and top tax contributor (about RMB1.08 billion or US\$0.13 billion in 2004).

The Xingwang Park represents a purpose-specific mobile telecommunications manufacturing cluster comprising Nokia-Capitel (the assembler) and up to 30 major suppliers to be coordinated by one logistics agent. While 17 suppliers (including parts making and services) had moved into the cluster by the end of 2004 (see Table 2), Nokia and BDA both expect that the number of suppliers will rise to about 30 after the second phase of the cluster is completed. Indeed, in the first half of 2005, the second phase of the Xingwang Park attracted four more suppliers and five extension projects of existing suppliers.. The cluster specializes in GSM mobile-phone manufacturing. Table 2 shows the major products, investment and home country of the 14 parts suppliers already in the cluster. According to Nokia-Capitel's marketing literature, the Xingwang Park represents “an important part of Nokia's global strategy. It is Nokia's global manufacturing base for high-tech products, based on its supply chain".

What then explains the emergence of the Xingwang Park as the leading mobile telecommunications manufacturing cluster in China? Apart from Nokia's strategic considerations explained earlier and BDA's easy access to local and regional expressway networks (see Figure 1), it is important to consider two key location-specific factors that account for the development of the Xingwang Park. First, and perhaps most significant, is the 
strong support provided by the central government - the so-called Beijing's "capital city effect". This locational advantage is obviously not available elsewhere in China. As the BDA is a state-level development zone in the national capital, it often gets attention from the Chinese top leaders (as no one would like to see its failure) and thus can enjoy special permission from the central government. Indeed, its management receives very strong support from the Beijing government and the State Council (Interviews with the BDA officials and Nokia-Capitel, November-December 2002). In their personal inscriptions presented to the BDA management in 1996 and 1997, two former vice premiers of the State Council, Wu Bangguo and Li Lanqing, note that the BDA is a development area epitomized by "a high starting point", "full of capital city's characteristics", and "making good use of the capital city advantage" (Originals in Chinese; reproduced in the BDA, n.d.: 21-22). For foreign firms, negotiating with the BDA, the joint venture partner of the Xingwang Park, is relatively easy as it has a shorter decision-making line. The BDA also enjoys special advantages unavailable in other development zones. Investments in the BDA are protected under laws passed in 1995. The BDA authority also enjoys investment approval right as high as a provincial government; i.e., it can approve investment projects up to US\$30 million, without having to seek permission from the State Council. This allows the provision of a one-stop service to most of its foreign investors. All these advantages enjoyed by the BDA amount to a form of joint action that characterizes industrial clusters in developing countries (see Schmitz, 1999; 2004; Schmitz and Nadvi, 1999).

Another aspect of this "capital city effect" is that law and legality tend to prevail much more in the BDA than elsewhere in China. While this relative lack of "institutional flexibility" in the policy environment might prove to be problematical for small and medium enterprises from such newly industrialized economies (NIEs) as Hong Kong and Taiwan that generally prefer the high degree of institutional flexibility common in south China (see Lever- 
Tracy et al., 1996; Hsing, 1998; Yeung, 2001; 2003; Yang, 2002), it is much more favourable for major global corporations like Nokia and its suppliers. As noted by one of Nokia's suppliers in the Xingwang Park,

... although Beijing is a little bit less flexible, at least you know what to expect. In Dongguang, and in southern China in general, things can be very flexible but when the person in charge changes or is arrested or executed then you don't know what's going to happen. They're not that predictable so I think this is a very good environment to do business. As long as you follow the letter of the law, then you know that you are safe. In southern China it's a wild west in that sense (Interviewed in Beijing, November 2002).

This fairly transparent nature of the institutional environment in Beijing enables long-term planning that remains vital to cluster formation. After all, by 2003, Nokia's investment in China had amounted to Euro1.7 billion (over US\$2.0 billion) and more than half of it was in Beijing. And the investment of Nokia and its major suppliers in the Xingwang Park alone was US\$1.2 billion. When the Xingwang Park goes into full operation, it is expected to generate annual sales of RMB $\$ 50$ billion (US\$6 billion) and create more than 25,000 job opportunities.

The second key location-specific factor is the availability of strong R\&D and labor market capabilities in the Beijing region. This common labor pool is one of the classic agglomeration economies that are used to explain cluster development (see Gordon and McCann, 2000). Several recent studies have shown the catalytic role of Beijing's institutional and academic environments in enhancing R\&D capabilities (Wang and Wang, 1998; Walcott, 2003; Zhou and Tong, 2003). At present, the number of scientists and engineers in Beijing accounts for one tenth of the national total (20 scientists and engineers per one thousand population, 11 times national average), and $R \& D$ expenditure per year incurred in Beijing accounts for $23.4 \%$ of the national total (with Beijing's local expenditure contributing to $8.6 \%) .{ }^{2}$ Besides, there are about 400,000 to 500,000 university/college students enrolled each year in Beijing, constituting a large pool of highly educated labor force. Indeed, the BDA has recently established a $\mathrm{PhD}$ workstation that serves as a platform for talent exchange and 
career development among R\&D scientists and engineers in Beijing. Moreover, Beijing's labor market for both skilled and unskilled labor also offers an added incentive to Nokia and its suppliers. While Beijing has one of the highest concentrations of leading universities and research institutes in China, it does not suffer as much from the high mobility in unskilled labor force associated with the "floating population" phenomenon that occurs in other parts of China. For example, recent studies have estimated that in such manufacturing locations in southern China as Dongguang and Guangzhou, over 90\% of workers are non-local residents who have hukou or household registration elsewhere in China (see Fan, 2001; 2002; Huang, 2001). In contrast, most workers in Beijing are local residents and thus labor recruitment and retention is less difficult. A major supplier to Nokia in the Xingwang Park has pointed to this important difference in the labor markets between Beijing and Dongguang:

Based on my past experience, the kind of operators they have. Most of those in Beijing actually live in Beijing. They live at home, we arrange buses for them to get to work and to go back home. And they are more likely to stay with us longer. In Dongguang, they come for two years, maximum three ... They come, they go back every Chinese New Year. They bring back money and after two or three years they go back. They have enough money to set up in business and then they leave. So it's very different. I think we are in a good situation here [in Beijing]. There are lots of good universities here - of course we are competing for the same engineers with other companies but at least they are here. And it's an attractive place to live and the operators happen to live here. They're not all from Beijing, but at least they have decided to make Beijing their home. So I think there's a big difference there (Interviewed in Beijing, November 2002).

\section{CAPITALIZING ON EXTERNAL ECONOMIES: NOKIA AND MAJOR}

\section{SUPPLIERS IN THE XINGWANG INDUSTRIAL PARK}

The above section offers a general overview of the emergence of the Xingwang mobile telecommunications manufacturing cluster in the BDA. There is little doubt that the cluster resembles the industrial complex model discussed in section two (see Table 1). Both Nokia-Capitel and its major suppliers in Table 2 enjoy substantial transport and logistical advantages through their close spatial proximity within the 100 hectares site. Such physical proximity also reduces production and information uncertainties inherent in the transactions 
between Nokia-Capitel and its suppliers - an important dimension of the localized external economies emanating from the Xingwang Park. Major suppliers can conveniently discuss and share market information with Nokia-Capitel via informal meetings. Since Nokia-Capitel does not make long-term production plans, suppliers have to figure out future market demand by themselves and decide on outsourcing needs based on their own market forecasts. This requires both formal and informal communications with Nokia managers - an uncertain industry situation favoring cluster formation (Maskell and Lorenzen, 2004). In the Xingwang Park, Nokia-Capitel has set up committees of management, logistics, operations, and administration that are made up of managers from Nokia-Capitel itself and all the suppliers in the park. The managers go together to Nokia-Capitel regularly to discuss ongoing issues that require improvement and to share other information related to production and market. Besides, Nokia-Capitel opens its catering center to all managers of suppliers in the industrial park so that managers can have close informal meetings and share tacit knowledge on markets and technology.

The industrial complex model, however, fails to explain the important role of trust in localizing inter-firm networks in the Xingwang Park. This dimension of "network effects" demonstrates the relevance of the social network model in Table 1 for explaining the initial participation of Nokia's global suppliers in setting up production facilities next to their major customer in the Xingwang Park. As early as spring 2000 when Nokia conducted its feasibility study, over 20 of its major suppliers worldwide had already committed to following Nokia to invest in the Xingwang cluster - a show of strong commitment or network tie to their principal customer. Nokia-Capitel also made it very clear right at the beginning that it would be the key driver of the cluster and would continue its close cooperation with all major suppliers on the basis of reasonable and honest partnership (Interview with Nokia-Capitel, November 2002). This trust relationship in Nokia's supplier network is evident in two aspects. 
First, all of the major suppliers in the Xingwang Park have been the preferred suppliers to Nokia worldwide. There is a significant degree of prior transactional relationship between Nokia-Capitel and these suppliers even before the establishment of the Xingwang Park. Second, Nokia-Capitel believes firmly in ensuring that the entire supply chain is profitable and thus prefers a partnership mode rather than a competitive sourcing strategy. This cooperative approach is very conducive for joint action to be developed that requires dedication by both Nokia-Capital and its major suppliers in terms of investment in the Xingwang park and production customization. For example, one supplier to Nokia-Capitel in the Park recalls how Nokia persuaded it to set up a production facility in the cluster without even any contractual agreement that guarantees a certain volume of production:

They say that 'it would be good if you have a factory there'. And then of course we want to get some guarantee about volumes to make sure we can cover our costs and are profitable. They don't give written guarantees - they say you will at least get this project. Then we believe that if we take good care of this business then we will get more (Interviewed in Beijing, November 2002).

This supplier invested in a facility in the Xingwang Park despite the fact that it is only an indirect supplier to Nokia, underscoring a high level of trust and commitment in Nokia's production networks in the Xingwang Park:

Of course, we are not direct supplier to Nokia. The injection moulder is our immediate customer, they pay our invoices. Nokia decides the prices but they do not pay. So we return our coated parts to injection moulder and then they deliver it to the assembler and then they deliver to Nokia. So everybody has the specifications and instructions and they are very strict. And no contracts. Everything is based on forecasts. It's flexible - from zero to $100 \%$ (Interviewed in Beijing, November 2002).

Apart from these cluster-specific external economies enjoyed by Nokia-Capitel and its major suppliers, there are also important and often-overlooked non-cluster based external economies that are more related to "network effects". We consider two aspects of these: (1) externalized synergy effects of clustering of firms and (2) enhanced production economies and capabilities through external customers. As explained earlier in section 2(b), firms in clusters can tap into external economies derived from outside these clusters. In the case of the 
Xingwang Park, Nokia-Capitel and its major suppliers enjoyed a great deal of collective bargaining power when they negotiated with the BDA and the central government. In particular, Nokia-Capitel was able to ensure that all land and tax privileges accrued to NokiaCapitel were also available to all Nokia's major suppliers in the Xingwang Park - a result of Nokia's initial bargaining with the relevant authorities. The right to utilize land in the Xingwang Park for twenty years, for example, was critical to capital-intensive investment among its major suppliers. In lieu of heavy capital investment in acquiring the land, each supplier needed only to pay various fees and taxes connected to the land in the Xingwang Park. One supplier notes that:

... we have to pay taxes. The taxes are connected to land. There are every year certain payments. You get land rights - in our case it's for 20 years. It belongs with Xingwang Industrial Park and we have a contract with them and in that contract they say we have to pay all fees in connection with this land area. We own the building (Interviewed in Beijing, November 2002).

Without the collective bargaining power of Nokia-Capitel on behalf of its major suppliers, it is doubtful that the latter would have gained the right to use the land free of acquisition or rents. This financial incentive represents a highly important form of external economies that Nokia was able to secure from the BDA and the central government. It represents a form of collective leverage that the lead firm of a major global production network can exercise over its local actors (cf. Schmitz, 1999; 2004; Schmitz and Nadvi, 1999). It also creates the possibility for Nokia's suppliers to set up production facilities in the Xingwang Park, further enhancing the initial process of cluster formation.

Other significant externalized synergy effects come from such sources of privileged access to BDA's trouble-shooting services and the general credibility and reputation as a member of the Xingwang Park. This joint action on the part of local actors is critical to entice the co-location of Nokia and its suppliers. Without being part of the Xingwang Park, most suppliers are unlikely to have access to the helpful assistance of the BDA and the Beijing 
government. One cluster supplier notes that without special assistance from the BDA, its factory building might not yet be operational:

It's been a big help. Maybe we would still have been building this factory. The big advantage is the link between the government, the local government and us (Interviewed in Beijing, November 2002).

Another supplier in the cluster also comments that

The local government in BDA seems to exist only to make our life easy. I've never seen anything quite like it - unbelievable. I've never seen this kind of service. I've been doing business with state enterprises in all sorts of manufacturing in China since 1986 and I've never seen it - it's unbelievable" (Interviewed in Beijing, November 2002).

Being part of the Nokia production network also enhances the reputation of its suppliers in dealing with non-cluster firms and institutions. One supplier comments that

Of course the Nokia word opens the door here. I have heard it's the biggest taxpayer in Beijing. There are a lot of government officers visiting here, asking what they can do for you and for Xingwang Park members (Interviewed in Beijing, November 2002).

These external economies of reputation and credibility go well beyond the cluster itself. In fact, many cluster members are well received when they approach other customers outside the Xingwang Park for marketing and business purposes (see below).

In the Xingwang Park, Nokia and its suppliers enjoy the treatment of a virtual bonded area, which helps to save customs processing time and cut down circulation capital (Liu etal., 2004: Figure 4). In China, firms pay different duties on imported parts and components according to where the finished products will go, i.e. to domestic or international markets. The Chinese central government also employs a value-added tax (VAT) refunding mechanism to promote exports. Firms, however, must first report to the Customs House to get approval of the import of parts and materials and pay duty first. All these procedures are conducted via a Customs Handbook and take considerable time. Thus, Nokia proposed to set up a virtual bonded area in the Xingwang Park, based on a computer network connecting Nokia-Capitel, suppliers in the Park, the logistics centre, and the BDA Customs House. In 2002, the State 
Customs House of China approved Nokia's proposal as a pilot project. The virtual bonded area enables Nokia and its suppliers in the Xingwang Park to enjoy convenient electronic customs procedures (save time) and pay duties after finished products are sold and shipped out (save circulation capital). Without Nokia's presence, the suppliers could hardly expect to receive such a preferential customs treatment.

The role of external customers in enhancing production economies and capabilities has thus been well recognized by Nokia-Capitel itself. Right from the beginning of the cluster conception, Nokia-Capitel wanted to ensure that its major suppliers would co-locate in the Xingwang Park and, yet, should not be excessively dependent on Nokia. It therefore asked its suppliers to sell up to $60 \%$ of their net sales to external customers over a reasonable period of time. One supplier thus recalls that

Because we are in Xingwang, the idea was that we do as much business as possible with Nokia. But of course Nokia has also told us that their target is that all park members should have no more than $40 \%$ of their net sales with Nokia (Interviewed in Beijing, November 2002).

The President of another major supplier from Finland, Elcoteq, said that "It is vital for Elcoteq to be a part of this industrial park project, which is regarded as the most important international industrial park for communications electronics in China. The Chinese market continues to grow, and the country is the largest mobile phone market in the world. So there is demand for electronics manufacturing services and for Elcoteq's particular expertise in wireless communications products" (http://www.conway.com/ssinsider/pwatch/pw011126.htm, accessed on 6 July 2005).

While this poses a difficult immediate target, given the dedicated production facilities set up by Nokia's suppliers, some cluster members are already seeking non-cluster customers and use that to leverage their production capabilities. For example, one supplier used to provide dedicated manufacturing services to Ericsson before the latter's demise in mobile telecommunications manufacturing. It has therefore learned the lesson of avoiding lock-in to 
one single customer. It is now using its facility in the Xingwang Park as a marketing lever to seek new customers nearby:

... we had a lot of cooperation with Ericsson earlier four or five years ago before Ericsson collapsed. There were a lot of projects in Finland but then zero. But now we have some projects in Guangzhou with Sony Ericsson. And also in Finland. Even so, $70-80 \%$ of the volume of work there is with Nokia. So the other projects are low volume projects. But they are important so that we can spread our customer range... Sony Ericsson is close to the airport so it's not a problem. Actually, everybody is here: Siemens is here, Panasonic is here, Motorola is in Tianjin. It [Xingwang] seems to be really the centre for mobile phone production (Interviewed in Beijing, November 2002).

Another major supplier to Nokia is engaged in providing electronic manufacturing services (EMS) in the form of modular production. Its "factories within a factory" concept revolves around factory organization in the form of different product lines, each serving a specific major customer and managed by a product line manager:

... we do not have a manufacturing department. We divide the company into what we call product lines and a product line is serving one particular customer in most cases if the customer is big enough. If the customer is small we just split - if our business with a customer is small we can combine several customers to one product line - noncompeting customers. And the product line manager, that post, covers anything from getting in customer forecasts, materials, manufacturing, shipping out, and invoicing customers and the product line manager is also responsible for the P\&L [profit and loss]. So we are in fact operating as a set of several factories (Interviewed in Beijing, November 2002).

This factory organization permits in-house production for customers outside the Xingwang Park: “For example, to serve a customer in Tianjin we don't need to set up a plant, we're close enough. Again we serve a customer in Beijing, not in the BDA, which has a supplier in southern China and we are by far the preferred supplier, I hope not only because of geographical location but that's certainly one factor, because it's money". In fact, this Nokia supplier used to have a manufacturing facility near to Sony Ericsson (located near the Beijing airport) that was established well before its facility in the Xingwang Park. The general manager, however, notes that the company has "moved to BDA and now we serve Sony Ericsson from BDA. It's less than an hour away". 


\section{CONCLUSION}

Cluster development is clearly a multi-dimensional process that is hard to be captured by any single causal explanation. While the three models proposed by Gordon and McCann (2000) and others (see Cumbers and MacKinnon, 2004; Perry, 2005) are grounded in particular theoretical interpretations of cluster formation and development, we find in this paper that the external economies accruing to firms in industrial clusters can be territorially derived from both cluster and non-cluster sources. This finding does not invalidate the theoretical and empirical importance of cluster-based external economies in explaining the growth and development of particular industrial clusters. However, these cluster-based external economies are only a necessary, but not sufficient, condition in explaining why clusters emerge in specific localities in the first place. Schmitz (1999: 468) has evidently argued that cluster-based external economies are "involuntary" and "incidental" in nature. They are therefore unable to explain intentional clusters that emerge out of deliberate force and collective action by local and global agents. In this paper, we examine the initial founding, and subsequent development, of a purpose-built industrial cluster located within the Beijing Economic and Technological Development Area that caters to mobile telecommunications equipment manufacturing spearheaded by the world's largest player in this industry - Nokia. We observe that while the external economies associated with spatial proximity have been important strategic considerations for Nokia-Capitel and its major suppliers, the eventual decisions of these firms to co-locate within the Xingwang (International) Industrial Park are complex and related to a variety of factors that are best described as "network effects".

More specifically, we find that closely-knit and partnership-based production networks can greatly enhance the relational proximity of Nokia and its major suppliers. This organizational mode does not necessarily call for physical clustering and co-location, though spatial proximity can further strengthen pre-existing relational proximity. The availability of 
non-cluster external economies, such as collective bargaining power and access to customers outside Nokia's production network, is critical in the strategic considerations of Nokia's major suppliers to co-locate in the Xingwang Park. As such, the development of the Xingwang Park as a leading mobile telecommunications cluster in China should be conceived as a spatial outcome of external economies associated with both non-cluster firms and institutions and cluster-specific production activities. Our conceptual and empirical analysis therefore points to the vital importance of broadening our existing conceptualization of the geographical sources of external economies in further explaining the formation and development of industrial clusters.

In making these theoretical and empirical observations, this paper can contribute to the emerging literature on industrial clusters in developing countries in two significant ways. First, our case study has shown explicitly how joint action and collective efficiency in these clusters can be shaped by the strength of network ties and bargaining power of lead firms operating in global production networks. A significant implication for economic development is that as developing countries are scrambling to develop industrial clusters, much more policy attention needs to be paid to how preconditions in specific localities in these countries can interact with the strategic requirements of lead firms and their key suppliers in global production networks. In other words, the nature of interactions between actors in localities (e.g. firms and governments) and global production networks can make a real difference to the creation, retention, and enhancement of value in industrial clusters (see Bair and Gereffi, 2001; Dicken et al., 2001; Henderson et al., 2002; Schmitz, 2004; Gereffi et al., 2005; Giuliani et al., 2005). Indeed, industrial clusters driven primarily by local small and medium enterprises are clearly very different in nature from those spearheaded by lead firms in global production networks (see the case in Latin America in Altenburg and Meyer-Stamer, 1999). 
Second, it is one thing to start a cluster and yet it is quite another to ensure its continual growth and evolution. While this paper has focused mostly on the formation stage of a cluster in China, there is still a great deal to be learnt about development issues from this sustainability perspective. Clearly the case of Nokia shows that the role of government policies can be highly important in swinging the locational decision of Nokia and its key suppliers. As the cluster gets off the ground and becomes self-sustaining, the role of government's locational policy may become less significant. Meyer-Stamer (2004: 340-41) has explained this "location paradox" for local economic development: "government can play a very important role in locational policy by helping local firms become so competitive that they are subcontracted by global buyers. However, as the firms get involved in the [global] value chain, the options in terms of government's role in locational policy declines substantially, and it can be expected that collective action in the private sector will suffer as well”. As more and more local firms in Beijing and elsewhere in China are involved in Nokia's production network either as a direct supplier to Nokia or a subcontractor to Nokia's key suppliers in the cluster, we can expect the role of the Chinese government to shift from direct locational policy to indirect institutional support that favors cluster growth through both Marshallian externalities and strengthening of external linkages to global production networks. Institutionalized supplier development programs, for example, can be an effective policy instrument to grow and sustain an industrial cluster that is well embedded in global production networks (Perry and Tan, 1998; Altenburg and Meyer-Stamer, 1999; Chew and Yeung, 2001). The continual enlargement of these external linkages will likely provide local suppliers and international firms an important window for technological upgrading and market expansion in the global economy. 


\section{NOTES}

${ }^{1}$ In 2002, an extension program of BDA was approved by the State Council of China, which enlarged BDA's area to 39.8 square kilometres.

${ }^{2}$ One major reason for such a high figure is that most of the national scientific academies in China are located in Beijing and they are supported by the central government's budget. 


\section{REFERENCES}

Altenburg, T. and Meyer-Stamer, J. (1999). How to promote clusters: policy experiences from Latin America. World Development, 27(9), 1693-713.

Amin, A. (2003) 'Spaces of corporate learning. in J. Peck and H.W.C. Yeung (eds.), Remaking the Global Economy, London: Sage, 114-29.

Amin, A. and Cohendet, P. (2004), Architectures of Knowledge: Firms, Capabilities and Communities, Oxford: Oxford University Press.

Amin, A. and Thrift, N. (eds.) (1994), Globalization, Institutions, and Regional Development in Europe, Oxford: Oxford University Press.

Bair, J. and Gereffi, G. (2001). Local clusters in global chains: the causes and consequences of export dynamism in Torreon's blue jeans industry. World Development, 29(11), 1885-903.

Bathelt, H., Malmberg, A. and Maskell, P. (2004). Clusters and knowledge', Progress in Human Geography, 28(1), 31-56.

Beijing Economic and Technological Development Area (n.d.), BDA 1992-2002, Beijing: BDA.

Benneworth, P. and Henry, N. (2004). Where is the value added in the cluster approach?', Urban Studies, 41(5-6), 1011-1023.

Bunnell, T.G. and Coe, N.M. (2001). Spaces and scales of innovation. Progress in Human Geography, 25(4), 569-90.

Cartier, C. (2001), Globalizing South China, Oxford: Blackwell.

Chew, Y.T. and Yeung, H.W.C. (2001). The SME advantage: adding local touch to foreign transnational corporations in Singapore. Regional Studies, 34(5), 431-48.

Christerson, B. and Lever-Tracy, C. (1997). The Third China? Emerging industrial districts in rural China. International Journal of Urban and Regional Research, 21(4), 569-588.

Coe, N., Hess, M., Yeung, H.W.C., Dicken, P. and Henderson, J. (2004). "Globalizing" regional development: a global production networks perspective. Transactions of the Institute of British Geographers, New Series, 29(4), 468-84.

Cooke, P.N. (2001), Clusters, Learning and Co-operative Advantage, London: Routledge.

Cumbers, A. (2000). Globalization, local economic development and the branch plant region: The case of the Aberdeen oil complex. Regional Studies, 34(4), 371-82.

Cumbers, A. and MacKinnon, D. (eds.) (2004). Special issue on "clusters in urban and regional development'. Urban Studies, 41(5-6), 959-1195. 
Depner, H. and Bathelt, H. (2005). Exporting the German model: the establishment of a new automobile industry cluster in Shanghai. Economic Geography, 81(1), 53-81.

Dicken, P. (2003), Global Shift, Fourth Edition, London: Sage.

Dicken, P., Kelly, P.F., Olds, K. and Yeung, H.W.C. (2001). Chains and networks, territories and scales: towards an analytical framework for the global economy. Global Networks, $1(2), 89-112$.

Duckett, J. (1998), The Entrepreneurial State in China, London: Routledge.

Ellison, G. and Glaeser, E.L. (1999). The geographic concentration of industry. American Economic Review, 89(2), 311-16.

Eng, I. (1999). Agglomeration and the local state: the tobacco economy of Yunnan, China. Transactions of the Institute of British Geographers, 24(3), 315-30.

Fan, C.C. (2001). Migration and labor-market returns in urban China', Environment and Planning A, 33(3), 479-508.

Fan, C.C. (2002). The elite, the natives, and the outsiders: Migration and labor market segmentation in urban China. Annals of the Association of American Geographers, 91(1), 103-24.

Fujita, M., Krugman, P. and Venables, A.J. (1999), The Spatial Economy: Cities, Regions, and International Trade, Cambridge, MA: MIT Press.

Fujita, M. and Thisse, J.-F. (1996). Economics of agglomeration. Journal of the Japanese and International Economies, 10, 339-78.

Fujita, K. and Hill, R.C. (1995). Global Toyotaism and local development. International Journal of Urban and Regional Research, 19(1), 7-22.

Gereffi, G., Humphrey, J. and Sturgeon, T. (2005). The governance of global value chains. Review of International Political Economy, 12(1), 78-104.

Gibbon, P. (2001). Upgrading primary products: a global value chain approach. World Development, 29(2), 345-63.

Giuliani, E., Pietrobelli, C. and Rabellotti, R. (2005). Upgrading in global value chains: lessongs from Latin American clusters. World Development, 33(4), 549-73.

Goodwin, M. and Painter, J. (1996). Local governance, the crises of Fordism and the changing geographies of regulation. Transactions of the Institute of British Geographers, 21(4), 635-48.

Gordon, I.R. and McCann, P. (2000). Industrial clusters: complexes, agglomeration and/or social networks?. Urban Studies, 37(3), 513-38. 
Henry, N., Pinch, S. and Russell, S. (1996). In pole positions? Untraded interdependencies, new industrial spaces and the British Motor Sport Industry. Area, 28(1), 25-36.

Hirschman, A. (1958), The Strategy of Economic Development, New Haven: Yale University Press.

Hsing, Y.T. (1998), Making Capitalism in China, New York: Oxford University Press.

Huang, Y. (2001). Gender, hukou, and the occupational attainment of female migrants in China (1985-1990). Environment and Planning A, 33(2), 257-79.

Humphrey, J. and Schmitz, H. (2002). How does insertion in global value chains affect upgrading in industrial clusters?. Regional Studies, 36(9), 1017-27.

Humphrey, J. and Schmitz, H. (2004a). Governance in global value chains. in H. Schmitz, (ed.), Local Enterprises in the Global Economy: Issues of Governance and Upgrading, Cheltenham: Edward Elgar, 95-109.

Humphrey, J. and Schmitz, H. (2004b). Chain governance and upgrading: taking stock. in H. Schmitz, (ed.), Local Enterprises in the Global Economy: Issues of Governance and Upgrading, Cheltenham: Edward Elgar, 439-81.

Lever-Tracy, C., Ip, D. and Tracy, N. (1996), The Chinese Diaspora and Mainland China, London: Macmillan.

Lin, G.C.S. (1997), Red Capitalism in South China, Vancouver: University of British Columbia Press.

Liu, W., Dicken, P. and Yeung, H.W.C. (2004). New information and communication technologies and local clustering of firms', Urban Geography, 25(4), 390-407.

Lloyd, P.E. and Dicken, P. (1972), Location in Space, New York: Harper \& Row.

Lovering, J. (1999). Theory led by policy: The inadequacies of the 'new regionalism', International Journal of Urban and Regional Research, 23(2), 379-95.

MacKinnon, D., Cumbers, A. and Chapman, K. (2002). Learning, innovation and regional development', Progress in Human Geography, 26(3), 293-311.

MacLeod, G. (2001a). Beyond soft institutionalism: accumulation, regulation, and their geographical fixes. Environment and Planning A, 33(7), 1145-167.

MacLeod, G. (2001b). New regionalism reconsidered: globalization and the remaking of political economic space. International Journal of Urban and Regional Research, 25(4)), 804-29.

MacLeod, G. and Goodwin, M. (1999). Space, scale and state strategy. Progress in Human Geography, 23(4), 503-27. 
Malmberg, A. (2003). Beyond the cluster - local milieus and global connections. in J. Peck and H.W.C. Yeung (eds.), Remaking the Global Economy, London: Sage, 145-59.

Malmberg, A. and Maskell, P. (2002). The elusive concept of localization economies', Environment and Planning A, 34(3), 429-49.

Markusen, A. (1996). Sticky places in slippery space: a typology of industrial districts. Economic Geography, 72(3), 293-313.

Markusen, A. (1999). Fuzzy concepts, scanty evidence, policy distance', Regional Studies, 33(9), 869-84.

Maskell, P. and Lorenzen, M. (2004). Cluster as market organisation. Urban Studies, 41(5/6), 991-1009.

Maskell, P. and Malmberg, A. (1999). Localised learning and industrial competitiveness. Cambridge Journal of Economics, 23(2), 167-185.

Martin, R. and Sunley, P. (2003). Deconstructing clusters: chaotic concept or policy panacea?. Journal of Economic Geography, 3(1), 5-35.

Marton, A.M. (2000), China's Spatial Economic Development, London: Routledge.

Meyer-Stamer, J. (2004). Paradoxes and ironies of locational policy in the new global economy. in H. Schmitz, (ed.), Local Enterprises in the Global Economy: Issues of Governance and Upgrading, Cheltenham: Edward Elgar, 326-48.

Morosini, P. (2004). Industrial clusters, knowledge integration and performance', World Development, 32(2), 305-26.

Perry, M. (2005), Business Clusters: An International Perspective, London: Routledge.

Perry, M. and Tan, B.H. (1998). Global manufacturing and local linkage in Singapore. Environment and Planning A, 30(9), 1603-624.

Phelps, N.A. (1992). External economies, agglomeration and flexible accumulation. Transactions, Institute of British Geographer, New Series, 17(1), 35-46.

Phelps, N.A. (2004). Clusters, dispersion and the spaces in between', Urban Studies, 41(5/6), 971-89.

Porter, M.E. (1998), On Competition, Boston: Harvard Business School Press.

Porter, M.E. (2000). Locations, clusters, and company strategy. in G.L. Clark, M.A. Feldman, and M.S. Gertler (eds.), The Oxford Handbook of Economic Geography, Oxford: Oxford University Press, 253-74.

Potter, J. and Moore, B. (2000). UK enterprise zones and the attraction of inward investment. Urban Studies, 37(8), 1279-312. 
Reid, N. (1995). Just-in-time inventory control and the economic integration of Japaneseowned manufacturing plants with the county, state and national economies of the United States. Regional Studies, 29(4), 345-56.

Sadler, D. (1994). The geographies of just-in-time: Japanese investment and the automotive components industry in Western Europe. Economic Geography, 70(1), 41-59.

Sayer, A. (1986). New development in manufacturing: the just-in-time system. Capital and Class, 30(1), 43-72.

Schmitz, H. (1999). Collective efficiency and increasing returns. Cambridge Journal of Economics, 23, 465-83.

Schmitz, H. (ed.) (2004), Local Enterprises in the Global Economy, Cheltenham: Edward Elgar.

Schmitz, H. and Nadvi, K. (1999). Clustering and industrialization: an introduction. World Development, 27(9), 1503-14.

Storper, M. (1995). The resurgence of regional economies, ten years later', European Urban and Regional Studies, 2(3), 191-221.

Storper, M. (1997), The Regional World, New York: Guilford Press.

Sturgeon, T.J. (2003). What really goes on in Silicon Valley?. Journal of Economic Geography, 3(2), 199-225.

Tallman, S., Jenkins, M., Henry, N. and Pinch, S. (2004). Knowledge, clusters, and competitive advantage. Academy of Management Review, 29(2), 258-71.

Walcott, S.M. (2003), Chinese Science and Technology Industrial Parks, Burlington, VT: Ashgate.

Wang J. and Wang, J.X. (1998). An analysis of new-tech agglomeration in Beijing: a new industrial district in the making?. Environment and Planning A, 30(4), 681-701.

Wang, J.H.J. and Yeung, H.W.C. (2000). Strategies for global competition: transnational chemical firms and Singapore's chemical cluster. Environment and Planning A, 32(5), 847-69.

Weber, A. (1909) Theory of the Location of Industries. Chicago: Chicago University Press.

Wolfe, D.A. and Gertler, M.S. (2004). Clusters from the inside and out', Urban Studies, 41(5/6), 1071-1093.

Womack, J.P., Jones, D.T. and Roos, D. (1990), The Machine That Changed the World, New York: Rawson Associates.

Yang, M.M.H. (2002). The resilience of guanxi and its new deployments', The China Quarterly, No.170, 459-76. 
Yeung, G. (2001), Foreign Investment and Socio-Economic Development in China, Basingstoke: Palgrave.

Yeung, G. (2003). Scramble for FDI: the experience of Guangdong province in southern China. in N.A. Phelps and P.Raines (eds.), The New Competition for Inward Investment, Cheltenham: Edward Elgar, 193-212.

Yeung, H.W.C. (2004). Enterprise zones. in S. Harrison, S. Pile and N. Thrift (eds.), Patterned Ground: Entanglements of Nature and Culture, London: Reaktion, 185-87.

Zhou, Y. and Tong, X. (2003). An innovative region in China: interaction between multinational corporations and local firms in a high-tech cluster in Beijing. Economic Geography, 79(2), 129-52. 
FIGURE 1. Xingwang Industrial Park and the Beijing Economic and Technological Development Area, China

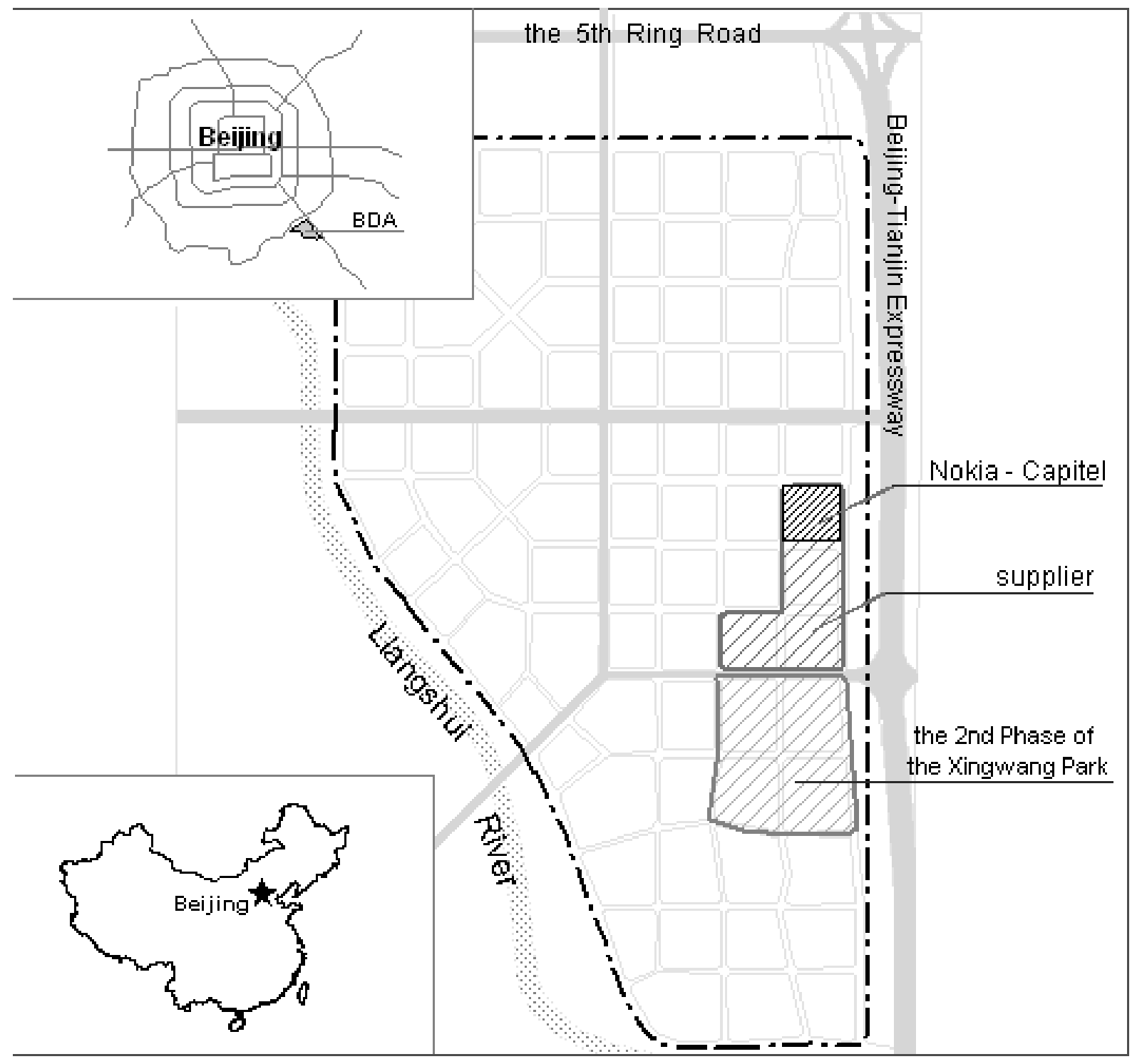


TABLE 1. Three Models of Industrial Clusters and External Economies

\begin{tabular}{|c|c|c|c|}
\hline $\begin{array}{l}\text { Model of } \\
\text { clusters }\end{array}$ & $\begin{array}{l}\text { Intellectual } \\
\text { traditions }\end{array}$ & $\begin{array}{l}\text { External economies accrued to } \\
\text { firms in clusters }\end{array}$ & $\begin{array}{l}\text { Territorial } \\
\text { sources }\end{array}$ \\
\hline $\begin{array}{l}\text { Pure } \\
\text { agglomeration } \\
\text { economies } \\
\text { model }\end{array}$ & $\begin{array}{l}\text { Neoclassical } \\
\text { economics after } \\
\text { Alfred Marshall }\end{array}$ & $\begin{array}{l}\text { 1. A local pool of specialized } \\
\text { labour (lower search costs) } \\
\text { 2. Local provision of non-traded } \\
\text { inputs (economies of scale) } \\
\text { 3. Maximum flow of information } \\
\text { and ideas (product and market } \\
\text { knowledge) }\end{array}$ & Within clusters \\
\hline $\begin{array}{l}\text { Industrial } \\
\text { complex model }\end{array}$ & $\begin{array}{l}\text { Location theory } \\
\text { after Alfred } \\
\text { Weber }\end{array}$ & $\begin{array}{l}\text { 1. Lower transport and logistics } \\
\text { costs } \\
\text { 2. Greater certainty in } \\
\text { transactions }\end{array}$ & Within clusters \\
\hline $\begin{array}{l}\text { Social network } \\
\text { model }\end{array}$ & $\begin{array}{l}\text { Embeddedness } \\
\text { in new economic } \\
\text { sociology }\end{array}$ & $\begin{array}{l}\text { 1. Localized trust and inter- } \\
\text { personal relationships } \\
\text { (relational assets) } \\
\text { 2. Institutionalized practices, e.g. } \\
\text { conventions and norms } \\
\text { (institutional thickness) }\end{array}$ & Within clusters \\
\hline
\end{tabular}

Source: Adapted from text in Gordon and McCann (2000). 
TABLE 2. Nokia and Its Major Suppliers in the Xingwang Industrial Park, Beijing

\begin{tabular}{|c|c|c|c|}
\hline Name of Manufacturers & Major Products & $\begin{array}{l}\text { Amount of } \\
\text { Investment } \\
\text { (US\$ million) }\end{array}$ & $\begin{array}{l}\text { Home } \\
\text { Country/Region }\end{array}$ \\
\hline 1. Nokia Capitel Telecommunications Ltd. & Mobile phones & 173.90 & Sino-Finland JV \\
\hline 2. Beijing Elcoteq Electronics Co. Ltd. & $\begin{array}{l}\text { Electronic parts } \\
\& \text { components }\end{array}$ & 29.00 & Finland \\
\hline $\begin{array}{l}\text { 3. Beijing GKI Electronics Co Ltd. (a JV } \\
\text { between IBM and China Great Wall) }\end{array}$ & $\begin{array}{l}\text { Electronic parts } \\
\& \text { components }\end{array}$ & 24.94 & Sino-US JV \\
\hline 4. Sanyo Energy (Beijing) Co. Ltd. & Batteries & 29.00 & Japan \\
\hline $\begin{array}{l}\text { 5. Nolato Mobile Communication } \\
\text { Polymers (Beijing) Co. Ltd. }\end{array}$ & $\begin{array}{l}\text { Polymer junction } \\
\& \text { parts }\end{array}$ & 7.10 & Sweden \\
\hline 6. Ibiden Electronics (Beijing) Co. Ltd. & $\begin{array}{l}\text { Printed wiring } \\
\text { boards }\end{array}$ & 29.90 & Japan \\
\hline 7. Sunarrow (Beijing) Electronics Co. Ltd. & Keymats & 12.00 & Hong Kong \\
\hline $\begin{array}{l}\text { 8. Foxconn Precision Component } \\
\text { (Beijing) Co. Ltd. }\end{array}$ & $\begin{array}{l}\text { Motherboard \& } \\
\text { Shell }\end{array}$ & 29.80 & Taiwan \\
\hline 9. RF Micro Devices (Beijing) Co. Ltd. & $\begin{array}{l}\text { Component test } \\
\& \text { pack }\end{array}$ & 29.99 & USA \\
\hline 10. Allgon Telecom (Beijing) Co. Ltd. & Antennas & 2.60 & Sweden \\
\hline $\begin{array}{l}\text { 11. Beijing Savcor Coatings Technologies } \\
\text { Co. Ltd. }\end{array}$ & Coatings & 4.50 & Finland \\
\hline 12. Molex Interconnect (Beijing) Co. Ltd. & $\begin{array}{l}\text { Interconnected } \\
\text { parts }\end{array}$ & 3.00 & Singapore \\
\hline 13. Friwo Electrical (Beijing) Co. Ltd. & Chargers & NA & Germany \\
\hline 14. Beijing S\&C Electronics Co. Ltd. & $\begin{array}{l}\text { Power-electronic } \\
\text { products }\end{array}$ & NA & USA \\
\hline $\begin{array}{l}\text { 15. Perlos (Beijing) Electronic and } \\
\text { Telecommunication Components Co. Ltd. }\end{array}$ & Plastics & NA & Finland \\
\hline $\begin{array}{l}\text { 16. Exel-Sinotrans Freight Forwarding } \\
\text { Co. Ltd. }\end{array}$ & Logistics service & NA & Sino-UK JV \\
\hline $\begin{array}{l}\text { 17. Beijing Ascendas-BETIDC } \\
\text { Development Co. Ltd. }\end{array}$ & $\begin{array}{l}\text { Road } \\
\text { management }\end{array}$ & NA & Singapore \\
\hline 18. Sodexho & $\begin{array}{l}\text { Housekeeping and } \\
\text { canteen service }\end{array}$ & NA & USA \\
\hline
\end{tabular}

NA: not available yet. JV: joint venture.

Source: Fieldwork in Beijing Economic and Technological Development Area, 2002, and Xingwang Newsletter, Issue 6 \& 7, 2005. 